\title{
GRA W NAZYWANIE Z PREFERENCYJNYM WYBOREM PARTNERÓW
}

\section{NAMING GAME WITH PREFERENCE PARTNER CHOICE}

\author{
Dorota Lipowska \\ INSTYTUT JĘZYKOZNAWSTWA, \\ UNIWERSYTET IM. ADAMA MICKIEWICZA \\ AL. NIEPODLEGŁOŚCI 4, 61-874 POZNAŃ
}

\begin{abstract}
In this paper, a naming game on an adaptive weighted network is examined. A weight of connection for a given pair of agents depends on their communication success rate and determines the probability with which the agents communicate. When the preference toward successfully communicating agents is not so strong, the model behaves similarly to the naming game on a complete graph. In particular, it quickly reaches a single-language state, albeit some details of the dynamics are different from the complete-graph version. Much different behaviour appears when the preference toward successfully communicating agents is stronger and the model gets trapped in a multi-language regime. In this case gradual coarsening and extinction of languages lead to the emergence of a dominant language, albeit with some other languages still being present. A comparison of distribution of languages in the model and in the human population is discussed.
\end{abstract}

\section{Modelowanie ewolucji języka}

W ostatnich latach coraz intensywniej badany jest problem genezy i ewolucji języka (Pinker i Bloom, 1990; Hurford, Studdert-Kennedy i Knight, 1998; Nowak i Krakauer, 1999; Knight, Studdert-Kennedy i Hurford, 2000; Briscoe, 2002; Christiansen i Kirby, 2003a; Gontier, van Bendegem i Aerts, 2006; Laks, 2008). Powstanie i rozwój języka to efekt interakcji trzech złożonych systemów adaptatywnych: człowiek jako gatunek podlega bowiem ewolucji biologicznej, jako członek społeczeństwa podlega oddziaływaniom kulturowym, a jako osobnik - procedurze nabywania języka (Christiansen i Kirby, 2003b; Kirby, 2007). Język możemy więc opisywać na poziomie ewolucyjnym, populacyjnym lub 


\section{Dorota Lipowska: Gra w nazywanie z preferencyjnym wyborem partnerów}

osobniczym. Choć procesy działające na tych różnych poziomach operują w różnych skalach czasowych (filogenetycznej, glossogenetycznej i ontogenetycznej), to jednak nie są niezależne, lecz wzajemnie na siebie wpływają. Dlatego właśnie dla adekwatnego opisu powstania i ewolucji języka potrzebne są bardzo skomplikowane modele, których przedstawienie $\mathrm{w}$ sposób analityczny wydaje się być zadaniem karkołomnym, jeśli nie wręcz niemożliwym. Ten niezwykle złożony problem charakteryzuje też wyjątkowa interdyscyplinarność i zajmują się nim obecnie badacze reprezentujący rzeczywiście różnorodne dziedziny naukowe.

Skupiając się na aspekcie kulturowym, można traktować język jako zbiór społecznie uznawanych konwencji stosowanych przez jego użytkowników w procesie komunikacji. Powstaje wówczas pytanie, jak owe konwencje się wyłaniały i rozwijały. Proponuje się różne modele tych procesów, oparte na mechanizmach uczenia się i kulturowej transmisji (Nowak i Komarova, 2001; Kirby, 2002; Steels, 2004; Brighton, Smith i Kirby, 2005). Obecnie najbardziej obiecującym i chyba najczęściej stosowanym podejściem do badania takich dynamicznych systemów złożonych wydają się być symulacje komputerowe (Cangelosi i Parisi, 2002; Christiansen i Kirby, 2003a; de Boer, 2006; de Oliveira, Stauffer, Wichmann i de Oliveira, 2008; Schulze, Stauffer i Wichmann, 2008), szczególnie zaś tzw. systemy wieloagentowe (Steels, 1997; Steels, 2000; Steels, 2002; Brighton, Kirby i Smith, 2003; Kirby i Christiansen, 2003) (Nolfi i Mirolli, 2010).

Do najbardziej znanych modeli opartych na procesach uczenia się $\mathrm{i}$ kulturowej ewolucji języka należą model iterowanego uczenia się (Iterated Learning Model) oraz model gier językowych (Language Games Model). W tym pierwszym (Kirby i Hurford, 2002; Smith, Kirby i Brighton, 2003; Scott-Phillips i Kirby, 2010) język przekazywany jest między kolejnymi generacjami agentów: generacja starszych produkuje wyrażenia językowe, na podstawie których agenty młodszego pokolenia uczą się danego języka. Następnie starsze agenty są zastępowane tymi młodszymi - a ich miejsce z kolei zajmuje nowe pokolenie i cały ten proces jest wielokrotnie powtarzany. W ten sposób badano między innymi proces przekształcania się języka holistycznego w kompozycyjny, wyłanianie się dialektów i odrębnych języków czy też kształtowanie się regularnych i nieregularnych form jezzykowych. Natomiast w modelu gier językowych (Steels, 1995; Steels, 2002; Steels, 2005) agenty nie są dzielone na odrębne generacje, między którymi odbywa się jednokierunkowa komunikacja i nie ma też wymiany pokoleń. Agenty mogą wchodzić z innymi w określone interakcje lingwistyczne zwane grami językowymi. Moga to być np. gra w naśladowanie, w nazywanie, w odróżnianie, w składanie (Steels, 1997; Steels, 2000; Loreto, Baronchelli, Mukherjee, Puglisi i Tria, 2011). Gry są rozgrywane wielokrotnie, każdorazowo między dwoma tylko agentami, a więc na poziomie lokalnym. W efekcie jednak w systemie rozprzestrzeniają się pewne wspólne dla wszystkich konwencje językowe. W ramach tego modelu badać więc można 
proces samoorganizacji komunikacji, na skutek której wyłania się w populacji globalna lingwistyczna koherencja (np. w wyżej wymienionych grach odpowiednio: wspólny zestaw dźwięków, słów, kategorii czy struktur składniowych).

Najprostszą grą językową jest wspomniana już gra w nazywanie (Naming Game) (Steels, 1995; Steels, 1996; Steels, 1997), w której agenty ustalają wspólne nazewnictwo dla pewnej liczby obiektów. Gra, rozgrywana sukcesywnie przez kolejne pary agentów, polega na komunikowaniu przez jednego agenta (mówcę) słowa wybranego z jego słownika drugiemu agentowi (słuchaczowi), a jej wynik (sukces lub porażka, w zależności od tego, czy słuchacz zna dane słowo) decyduje o przebiegu procesu uczenia się języka poprzez odpowiednie modyfikowanie słowników obu agentów. Ostatecznie prowadzi to do wyłonienia się wspólnego dla wszystkich agentów języka, tzn. konwencji przyporządkowującej poszczególnym obiektom ich nazwy. Należy tu raz jeszcze podkreślić, że chociaż gra w nazywanie przebiega na poziomie stricte lokalnym, jako że obywa się ona bez jakiejkolwiek centralnej kontroli i każdorazowo angażują się w nią tylko dwa agenty nie posiadające żadnej wiedzy o systemie jako całości ani też o poszczególnych innych agentach, to jednak końcowy rezultat wyłania się globalnie (w formie języka wspólnego dla całej populacji).

W oryginalnym sformułowaniu modelu Steelsa w układzie jest wiele obiektów; zaproponowane też zostały różne odmiany tej podstawowej wersji (Steels i McIntyre, 1999; Lenaerts, Jansen, Tuyls i de Vylder, 2005; Lipowski i Lipowska, 2009). Liczne badania przeprowadzono ponadto dla tzw. modelu minimalnego, czyli maksymalnie uproszczonej wersji jednoobiektowej, która jednak w zupełności wystarcza do wyznaczenia podstawowej dynamiki tego modelu (Baronchelli, Felici, Loreto, Caglioti i Steels, 2006; Loreto, Baronchelli, Mukherjee, Puglisi i Tria, 2011; de Vylder i Tuyls, 2006). Badane także były różnie zmodyfikowane warianty modelu, np. ewolucyjny (Lipowski i Lipowska, 2008; Lipowska, 2011b), transmisyjny (Lu, Korniss i Szymanski, 2006), negocjacyjny (Baronchelli, Dall'Asta, Barrat i Loreto, 2007), chemiczny (De Beule, 2011), z zewnętrznym leksykonem (da Silva Filho, Brust i Ribeiro, 2009) i inne.

Istotnym elementem definicji modelu gry w nazywanie jest topologia interakcji między agentami. Innymi słowy, jeśli agenty traktować jako wierzchołki grafu, a interakcje między nimi jako krawędzie tego grafu, to można badać, jak gra w nazywanie przebiega na różnego rodzaju grafach. Najprostszy przypadek to model na grafie pełnym, gdzie każdy agent może się komunikować z każdym innym (Steels, 1995; Baronchelli, Felici, Loreto, Caglioti i Steels, 2006; Baronchelli, Loreto i Steels, 2008). Analizowano też sieci regularne, gdzie interakcje zachodzą wyłącznie między najbliższymi sąsiadami (Baronchelli, Dall'Asta, Barrat i Loreto, 2005; Lipowska, 2011b). Oczywiście rzeczywiste sieci społecznych oddziaływań są znacznie bardziej skomplikowane (Wasserman i Faust, 1994; White, Boorman i Breiger, 1976; Albert i Barabási, 2002). Stąd, aby uwzględnić ich heterogeniczną naturę, badano również modele na sieciach 


\section{Dorota Lipowska: Gra w nazywanie z preferencyjnym wyborem partnerów}

małych światów (Dall'Asta, Baronchelli, Barrat i Loreto, 2006a; Lin, Ren, Yang i Wang, 2006; Liu, Jia, Yang i Wang, 2009), sieciach bezskalowych (Dall'Asta, Baronchelli, Barrat i Loreto, 2006b; Baronchelli, Loreto, Dall'Asta i Barrat, 2006), losowych grafach geometrycznych (Lu, Korniss i Szymanski, 2006; Lu, Korniss i Szymanski, 2008), czy też sieciach o narzuconej strukturze klasterowej (Dall'Asta, Baronchelli, Barrat i Loreto, 2006b; Lu, Korniss i Szymanski, 2009). Mimo pewnych ilościowych różnic w dynamice tych wszystkich modeli, ogólne ich zachowanie, mianowicie szybka zbieżność do stanu pełnej synchronizacji całej populacji (tj. do stanu jednojezykowego), jest zawsze takie samo. Jedyny tu wyjątek, w dodatku właściwie potwierdzający ogólną zasadę, stanowi ostatni z wyżej wymienionych rodzaj sieci, mianowicie tworzonych z bardzo słabo ze sobą powiązanych (np. tylko pojedynczą krawędzią) klasterów o bardzo licznych wewnętrznych połączeniach międzywęzłowych (w szczególności tzw. klik, czyli podgrafów pełnych). W takich strukturach gra w nazywanie także prowadzi do synchronizacji, ale tylko w ramach klasterów (innymi słowy, choć w populacji może pozostać wiele języków, to występowanie każdego z nich będzie ograniczone do oddzielnej grupy).

Typowy dla gry w nazywanie jest więc stan finalny, w którym wszystkie osobniki znają ten sam język. Czy tak właśnie potoczy się też ewolucja języka naturalnego, czy wszyscy ludzie będą kiedyś posługiwać się jakimś wspólnym dla wszystkich językiem? Jest to oczywiście możliwe, ale nie można też wykluczyć, że to aktualny stan wielojęzykowej populacji okaże się stanem stabilnym (tyle że zapewne ze znacznie mniejszą niż obecnie liczbą języków). Jak już wspomniano, w grze w nazywanie także już odnotowano pojawienie się takich wielojęzykowych stanów dla pewnych specyficznych sieci złożonych o określonej strukturze (Dall'Asta, Baronchelli, Barrat i Loreto, 2006b), jednakże był to efekt uzyskany, jak to określili sami autorzy, w nieco sztuczny sposób, przez planowe skonstruowanie odpowiedniej sieci. Można jednak sądzić, że taka pożądana (z punktu widzenia modelowania ewolucji języka naturalnego) struktura wielojęzykowa winna pojawiać się raczej jako rezultat jakiegoś dynamicznego procesu. Warunek ten spełnia prezentowany poniżej model gry w nazywanie prowadzący właśnie do stabilnych stanów wielojęzykowych. Komunikacja między agentami w tym modelu ma odzwierciedlać pewną cechę interakcji społecznych. Zakładamy tu mianowicie, że tym chętniej i częściej oddziaływuje się z danymi partnerami, im bardziej były udane wcześniejsze kontakty z nimi. Dlatego też model zdefiniowany jest tu na ważonym grafie pełnym, przy czym wagi połączeń między poszczególnymi agentami decydują o prawdopodobieństwie ich interakcji. Ponadto wagi te są zmienne, gdyż zależą od poziomu sukcesu komunikacyjnego osiągniętego dotychczas przez daną parę agentów. Oznacza to, że prezentowany tu model topologicznie odpowiada pewnego rodzaju sieci złożonej, a mianowicie adaptatywnej sieci ważonej. 


\section{Definicja modelu}

Rozważana jest populacja $N$ agentów rozgrywających między sobą jednoobiektową grę w nazywanie. Każdy agent wyposażony jest w słownik, czyli listę znanych sobie słów odnoszących się do owego obiektu (początkowo wszystkie słowniki są puste). Gra przebiega w następujący sposób:

1. Spośród wszystkich agentów losowany jest mówca (każdy $\mathrm{z}$ jednakowym prawdopodobieństwem ).

2. Spośród pozostałych agentów losowany jest słuchacz. Jeśli mówcą jest $i$-ty agent, to prawdopodobieństwo $p_{i j}$ wyboru $i$-tego agenta na słuchacza wynosi

$$
p_{i j}=\frac{w_{i j}}{\sum_{k=\mathbf{1}}^{N} w_{i k}}
$$

gdzie $w_{i j}$ to następujące wagi przypisane poszczególnym parom agentów:

$$
w_{i j}= \begin{cases}s_{i j}+\varepsilon & d l \mathbf{a} i \neq j \\ 0 & d l \mathbf{a} i=j\end{cases}
$$

dla $i, j=1, \ldots, N$. Parametr $\varepsilon$ jest minimalną wartością wagi dla każdej pary różnych agentów. Jego wartość jest dodatnia, ale typowo bardzo

mała $(0<\varepsilon \ll 1)$. Wielkość $s_{i j}$, czyli dotychczasowy poziom sukcesu komunikacyjnego danej pary agentów $(i, j)$, zdefiniowana jest poniżej.

3. Mówca wybiera losowo jedno słowo ze swojego słownika (w przypadku gdy słownik jest jeszcze pusty, agent generuje losowo nowe słowo) i jest ono komunikowane słuchaczowi.

4. Gra kończy się

a) sukcesem - o ile słuchacz zna dane słowo, tzn. ma je w swoim słowniku - i wówczas oba agenty pozostawiają $\mathrm{w}$ swoich słownikach wyłącznie to właśnie słowo,

b) porażką - w przeciwnym przypadku - i wtedy słuchacz dodaje to słowo do swojego słownika.

5. Dla pary agentów $(i, j)$ uaktualnione zostają liczba ich dotychczas wspólnie odniesionych sukcesów oraz liczba wszystkich wspólnie rozegranych gier, a iloraz tych dwóch liczb wyznacza aktualny 


\section{Dorota Lipowska: Gra w nazywanie z preferencyjnym wyborem partnerów}

poziom ich wzajemnego sukcesu komunikacyjnego $s_{i j}=s_{j i}$ (początkowy poziom ${ }^{s_{i j}}=\mathbf{0}$ dla wszystkich par agentów).

Jak widać, gra $\mathrm{w}$ nazywanie jest tu zdefiniowana $\mathrm{w}$ typowy sposób, odpowiadający - pominąwszy wagi i związaną z nimi strategię wyboru słuchacza - tzw. modelowi minimalnemu (Baronchelli, Felici, Loreto, Caglioti i Steels, 2006). Jedyną różnicę stanowi właśnie krok drugi powyższej procedury, który ma realizować wspomniane wcześniej kryterium wyboru partnera do komunikacji, polegające na tym, że bardziej wolimy kontaktować się z tymi, z którymi już uprzednio lepiej się porozumiewaliśmy. W modelu preferencję tę wyznaczają wagi, według których określa się prawdopodobieństwo komunikacji, a które z kolei same zależą od poziomu sukcesu komunikacyjnego poszczególnych par agentów. Oczywiście w trakcie kolejnych interakcji agentów wartości te ulegają zmianom, dlatego też omawiany model odpowiada adaptatywnej sieci ważonej. Przebieg ewolucji całego systemu wyznaczają więc wagi, które określają intensywność komunikacji między agentami. Generalnie, im większy poziom sukcesu komunikacyjnego pary agentów, tym częściej będą się one ze sobą komunikować. Zauważmy jednak, że ze względu na niezerową wartość parametru $\epsilon$ występującego w definicji wagi, dla dowolnych dwóch agentów, nawet takich, które nie odniosły ze sobą jeszcze żadnych sukcesów, zawsze istnieje choćby minimalna szansa ich komunikacji.

Na samym starcie ewolucji modelu wszystkie wagi $w_{i j}=\varepsilon \quad$ (dla $i \neq j$ ), a więc mówca $\mathrm{z}$ takim samym prawdopodobieństwem wybiera dowolnego agenta jako swojego słuchacza. W początkowej fazie ewolucji systemu, gdy agenty mają jeszcze puste słowniki, generowana jest duża liczba nowych słów. Ponieważ większość interakcji kończy się wtedy porażką, to wagi nie podlegają większym zmianom. Stopniowo jednak zaczynają pojawiać się też sukcesy, co powoduje zwiększanie odpowiednich wag dla pewnych par agentów. Na skutek tego dany agent będzie się w dalszym ciągu komunikować z niektórymi agentami częściej niż z innymi, a to po pewnym czasie prowadzi do utworzenia się klastera agentów znających to samo słowo, a więc mogących się ze sobą skutecznie porozumiewać. Wzrastające dzięki temu ich wzajemne preferencje (wagi) powodują, że ich próby komunikowania się koncentrują się wewnątrz klastera, w którym wobec tego szybko osiągnięty zostaje stan lingwistycznej synchronizacji: wszystkie jego agenty posługują się tym samym językiem, to znaczy posiadają $w$ swoich słownikach wyłącznie jedno wspólne słowo.

Oczywiście struktura sieci agentów wyznaczona przez wagi jest dynamiczna i nawet bardzo silne połączenia między nimi (tj. o wagach bliskich jedności) mogą z czasem osłabnąć, podobnie jak też słabe więzi mogą stopniowo ulec wzmocnieniu. Odpowiedzialny za to jest parametr $\varepsilon$ stanowiący minimalną (dodatnią) wartość wagi. Powoduje on, że dla dowolnej pary agentów prawdopodobieństwo ich interakcji jest zawsze 
niezerowe. Porozumiewanie się z agentami spoza własnego klastera może zaś spowodować zmianę klastera, do którego należy agent. Takie procesy prowadzą do rozwoju jednych klasterów kosztem innych, które z kolei mogą nawet ulec rozpadowi.

Szczegóły tej dynamiki oraz stan końcowy ewoluującego tak układu zależą od parametrów $^{\varepsilon}$ oraz $^{N}$. Jest oczywiste, że im większa jest wartość $\varepsilon$, tym częstsze są interakcje agentów $\mathrm{z}$ partnerami spoza własnego klastera. Podobnie jednak wpływa na intensywność takiej pozaklasterowej komunikacji liczba agentów ${ }^{N}$, ponieważ w dużych systemach agent należący do pewnego skończonego klastera ma tak wielu kandydatów na słuchaczy spoza tego klastera, że mimo minimalnej dla każdego z nich preferencji, w sumie istnieje duża szansa wyboru właśnie któregoś z nich. Można też oczekiwać, że to nie każdy $\mathrm{z}$ parametrów $\varepsilon \mathrm{i}^{N} \mathrm{z}$ osobna kontroluje system, lecz raczej jakaś ich kombinacja. Choć brak jeszcze ścisłego na to dowodu, w pracy (Lipowska, 2011a) przedstawione sa pewne argumenty na rzecz tego, że rolę parametru kontrolnego modelu pełni iloczyn $N \varepsilon^{2}$.

\section{Symulacje komputerowe modelu}

W celu dokładniejszej ilościowej analizy opisanego modelu przeprowadzone zostały jego komputerowe symulacje. Badano zachowanie modelu dla populacji o różnej liczbie agentów $N$. Dla właściwego porównania obserwowanych charakterystyk tych układów, zmiennych oczywiście w trakcie ewolucji, zdefiniowano w modelu jednostkę czasu jako $N$ interakcji między parami agentów (co oznacza, że w tym czasie każdy agent, średnio rzecz biorąc, raz podejmuje próbę komunikacji jako mówca). Podstawowymi parametrami, których wartości mierzono w trakcie symulacji były ${ }^{s}, L$ oraz $N_{d}$, określone jak następuje:

- Sukces komunikacyjny $s$ zdefiniowany jest jako odsetek wszystkich sukcesów odniesionych przez agenty w ciągu ubiegłej jednostki czasu, tj. w ciągu ostatnich $N$ interakcji między nimi. Zwróćmy uwagę, że parametr $s$ odpowiada wyłącznie aktualnemu, tzn. wyliczonemu dla ostatniej jednostki czasu, poziomowi średniego sukcesu całego układu, podczas gdy parametry $s_{i j}$ opisują poziom sukcesu odniesionego dotychczas (licząc od samego początku ewolucji układu) przez daną parę agentów, a więc niejako przechowują w sobie całą historię kontaktów między tymi dwoma agentami.

- Parametr ${ }^{L}$ to liczba różnych słów przechowywanych w słownikach wszystkich agentów. Na późniejszych etapach symulacji, gdy większość agentów ma już tylko po jednym słowie w swoich słownikach, $L$ można interpretować jako liczbę języków używanych przez agenty w danym momencie ewolucji systemu. 


\section{Dorota Lipowska: Gra w nazywanie z preferencyjnym wyborem partnerów}

- Wielkość $N_{d}$ oznacza liczbę agentów używających dominującego języka, tzn. posiadających $w$ słownikach najpopularniejsze $w$ układzie słowo (to, które występuje w największej liczbie słowników).

W celu zredukowania statystycznych fluktuacji, te mierzone wielkości $s, L$ i $N_{d}$ uśredniano względem liczby (zwykle rzędu 100) niezależnych przebiegów symulacji modelu. Wyniki zebrane dla układów o różnej wielkości ${ }^{N}$ (przy ustalonej jednocześnie wartości parametru kontrolnego modelu $N \varepsilon^{2}$ ) wykazują dobrą zbieżność badanych wielkości ze wzrostem $N$. Jednocześnie pokazują one, że zachowanie modelu może być dwojakie, w zależności od wartości parametru kontrolnego $N \varepsilon^{2}$. Jeśli $N \varepsilon^{2}$ jest dostatecznie duże, to model zachowuje się $\mathrm{w}$ sposób typowy dla gry $\mathrm{w}$ nazywanie na grafie pełnym, a w szczególności bardzo szybko osiąga stan pełnej lingwistycznej synchronizacji (aczkolwiek pewne szczegóły jego dynamiki są odmienne). Natomiast gdy $N \varepsilon^{2}$ jest odpowiednio małe, to zachowanie modelu zupełnie się zmienia i ostatecznie to stan różnorodności językowej okazuje się być stanem stabilnym modelu. Oba te reżimy działania systemu - jedno- i wielojęzykowy - przedstawione są bardziej szczegółowo w kolejnych paragrafach.

\section{Reżim jednojęzykowy}

Przy dostatecznie dużej wartości parametru kontrolnego modelu $N \varepsilon^{2}$ (np. $10^{-5}$ ) stosunkowo słabsze staje się preferowanie przez agenty partnerów, z którymi skutecznie się dotąd komunikowały, a wzrasta częstotliwość komunikacji pozaklasterowej. Dlatego też $\mathrm{w}$ tym przypadku model zachowuje się analogicznie jak w klasycznym przypadku grafu pełnego, dla którego wykazano szybką zbieżność do stanu globalnej synchronizacji (jak wiadomo, następuje $\mathrm{w}$ takim systemie gwałtowne przejście ze stanu nieuporządkowanego do uporządkowanego, czyli $\mathrm{z}$ wielo- do jednojęzykowego (Baronchelli, Felici, Loreto, Caglioti i Steels, 2006)). Symulacje omawianego tu modelu potwierdziły zasadniczo takie właśnie zachowanie, wykazując jednak także pewne różnice.

Dynamikę modelu w tym reżimie ilustruje Ryc. 1. I tak, w pierwszym kroku symulacji głównie generowane są nowe słowa $\left(N_{1}\right.$, czyli liczba agentów z jednym słowem w słowniku, osiąga wtedy prawie połowę liczby agentów). W kilku kolejnych krokach liczba $N_{1}$ szybko maleje, gdyż większość prób komunikacji wówczas zawodzi, a więc agenty uczą się nowo poznanych słów, dołączając je do swoich słowników (odpowiednio liczba $M$ wszystkich słów w słownikach agentów szybko rośnie). To wreszcie zaczyna owocować coraz większym powodzeniem komunikacji, znów powodującym wzrost liczby $N_{1}$ i spadek liczby $M$ (w dalszym ciągu $\underline{N_{1}}$

odsetek $\bar{N}$ zmienia się już analogicznie jak poziom sukcesu). Od tego więc momentu poziom sukcesu komunikacyjnego ${ }^{s}$, początkowo bliski zeru, 
zaczyna szybko rosnąć (do około 80\%); jest to bowiem faza, w której tworzą się klastery (tzn. grupy agentów posługujących się tym samym językiem) i właśnie skuteczność odbywającej się wewnątrz nich komunikacji zapewnia tu stosunkowo wysoki poziom sukcesu. Klastery te są jednak niewielkie i bardzo liczne, a co za tym idzie, niezbyt stabilne. Dalej następuje więc okres przejściowy, w którym poziom ${ }^{s}$ się stabilizuje, nieco się nawet obniżając; jest to bowiem etap zmian wstrukturze poszczególnych klasterów (tzw. coarsening), w którym niektóre klastery powiększają się kosztem innych - w szczególności zaś zaczyna wyłaniać się język dominujący, którego używa coraz więcej agentów - a takim przenosinom agentów pomiędzy klasterami towarzyszy właśnie chwilowe obniżenie poziomu sukcesu $s$. W efekcie niektóre klastery $\mathrm{w}$ ogóle zanikają, a więc spada liczba języków $L$. I wreszcie następuje moment $(t \approx 700)$, w którym nie tylko zostaje już niewielka w porównaniu z początkową liczba klasterów - a więc i liczba języków będących w użyciu $L$ - ale także zdecydowanie wyróżnia się wśród nich klaster największy (tzw. giant cluster, obejmujący znaczącą większość agentów), czyli zaczyna w układzie dominować jeden z języków: liczba $\frac{N_{d}}{N}$, dotychczas stale niewiele większa od zera, teraz skokowo rośnie do jedności, a więc dominujący język błyskawicznie obejmuje prawie całą populację. To powoduje równie gwaltowny wzrost aktualnego poziomu sukcesu komunikacyjnego $s$ do niemal 100\%. Co ciekawe, układy o różnej wielkości ${ }^{N}$ osiągają te maksymalne wartości obu badanych parametrów mniej więcej w tym samym momencie czasu $(t \approx 750)$. W każdym razie niewątpliwie mamy tu do czynienia z przejściem ze stanu lingwistycznej różnorodności do stanu lingwistycznej synchronizacji. Chociaż w tym czasie znormalizowana liczba używanych języków $\frac{L}{N}$ dąży już do zera, to jednak nadal pozostaje jeszcze w użyciu kilka czy kilkadziesiąt języków. Jednakże i one szybko są eliminowane i zastępowane przez język dominujący, aż wreszcie układ staje się $\mathrm{w}$ pełni jednorodny (jednojęzykowy, tj. $L=1$ ). 
Dorota Lipowska: Gra w nazywanie z preferencyjnym wyborem partnerów

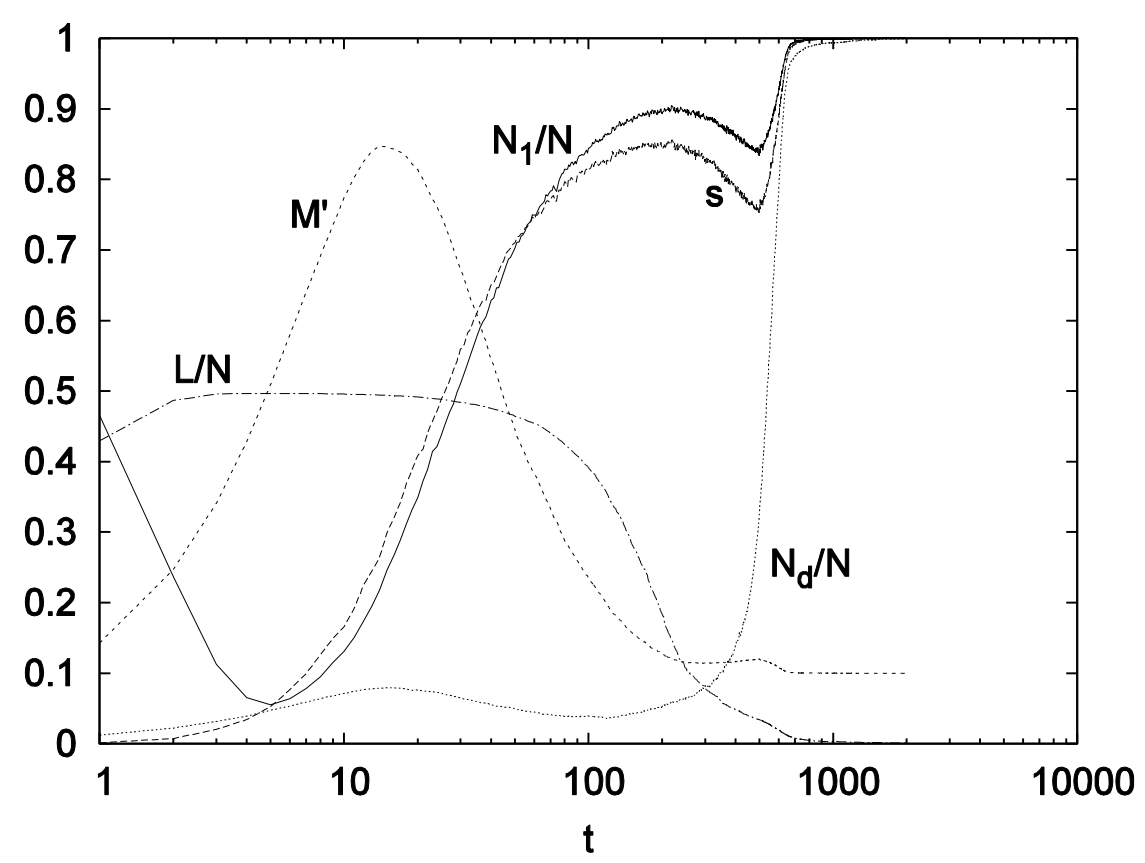

Ryc. 1 Zależność wartości pięciu parametrów modelu od czasu t (oś pozioma $w$ skali logarytmicznej) wyznaczona $w$ uktadzie o liczbie agentów $N=1000$ przy wartości parametru kontrolnego $N \varepsilon^{2}=10^{-5}$, czyli w reżimie jednojęzykowym. Te parametry to: (1) sukces komunikacyjny s, (2) stosunek liczby różnych stów do liczby agentów $\frac{L}{N}$, (3) odsetek agentów z jednym stowem $w$ stowniku $\frac{N_{1}}{N}$, (4) odsetek agentów używających dominującego języka $\frac{N_{d}}{N}$, (5) stosunek liczby $M$ wszystkich stów $w$ stownikach agentów do liczby agentów $N$

$$
\text { przeskalowany przez } 10, \text { tzn. }{ }^{M^{\prime}}=\frac{M^{\prime}}{10^{4}} \text {. }
$$

Jak wiadomo, charakterystyczny czas $\tau$, w którym w grze w nazywanie osiągany jest stan jednojęzykowy, rośnie wraz ze wzrostem wielkości układu $^{N}$; przykładowo, na grafie pełnym $\tau$ wzrasta jak $N^{\frac{3}{2}}$ (Baronchelli, Felici, Loreto, Caglioti i Steels, 2006). Natomiast wyniki symulacji omawianego tu modelu wskazują na zaskakującą odmienność jego zachowania pod tym względem, mianowicie czas charakterystyczny $\tau$ nie dąży tu do nieskończoności wraz z ${ }^{N}$, lecz najprawdopodobniej dąży do pewnej skończonej wartości (rzędu $t=1000$, co jest w przybliżeniu zgodne ze skalą czasową wynikającą z zachowania innych parametrów modelu, takich jak $s, L$ czy $\frac{N_{d}}{N}$ ). Niewykluczone - choć trudno to na razie 
jednoznacznie potwierdzić - że to nietypowe zachowanie się modelu jest efektem ubocznym wywołanym przez formę parametru kontrolnego modelu $N \varepsilon^{2}$. Ponieważ wyniki poszczególnych symulacji porównywane są przy ustalonej jego wartości, to przy zwiększaniu $N$ automatycznie zmniejszany jest $\varepsilon$, a więc zmienia się siła preferencji doboru partnerów, zaś intensywność kontaktów między różnymi agentami rzeczywiście może wpływać na tempo, w jakim system osiąga stan lingwistycznej synchronizacji.

Inną jeszcze wielkością, której zachowanie zostało porównane ze znanymi wynikami, jest liczba $M$ wszystkich słów przechowywanych $\mathrm{w}$ słownikach agentów. I znów, wiadomo, że dla grafu pełnego w trakcie ewolucji systemu liczba ta najpierw stopniowo rośnie, a następnie powoli maleje w miarę jak układ zbliża się do stanu jednojęzykowego, by wreszcie ustabilizować się na poziomie liczby agentów $N$. W omawianym modelu wielkość ta zachowuje się analogicznie (na Ryc. 1 jest to wielkość ${ }^{M^{\prime}}$, przeskalowana w stosunku do oryginalnej liczby ${ }^{M}$ przez $10^{4}$ ). Oczywiście maksymalna wartość $M$ zależy od wielkości układu. Jak pokazano, maksymalna liczba wszystkich słów (znormalizowana przez liczbę agentów $N$ ) ze wzrostem ${ }^{N}$ rośnie asymptotycznie jak $N^{0.5}$ (Baronchelli, Felici, Loreto, Caglioti i Steels, 2006). Natomiast w przedstawionym modelu wzrost ten jest proporcjonalny do $N^{0.45}$. Ta ilościowa różnica jest jeszcze jednym potwierdzeniem faktu, że dynamika tego modelu, mimo zasadniczych podobieństw, nie jest jednak identyczna z dynamiką gry $\mathrm{w}$ nazywanie na prostym grafie pełnym.

\section{Reżim wielojęzykowy}

Gdy parametr kontrolny modelu $N \varepsilon^{2}$ ma dostatecznie małą wartość (np. $10^{-9}$ ), to komunikacja pozaklasterowa jest tak niezwykle rzadka, że skutkuje to zupełnie innym zachowaniem modelu niż w poprzednim przypadku. Chociaż także tutaj sukces komunikacyjny ${ }^{s}$ dość szybko zbliża się do jedności (dla $t \approx 1000$ - zob. Ryc. 2), jednakże odsetek użytkowników dominującego języka wynosi wówczas zaledwie kilka procent. Wzrasta on znacząco dopiero po znacznie dłuższym czasie $(t \approx 30000)$. Nawet wtedy jednak wciąż nie obejmuje to całej populacji i w użyciu pozostaje duża liczba innych języków. Chociaż liczba ta powoli maleje, to jednak nie do jedności. Jak pokazują wyniki symulacji, sytuacja stabilizuje się około $t \approx 10^{5}$ z około dziesięcioma językami $(L \approx 10$ ) w systemie i pozostaje bez zmian do $t \approx 10^{6}$. 
Dorota Lipowska: Gra w nazywanie z preferencyjnym wyborem partnerów

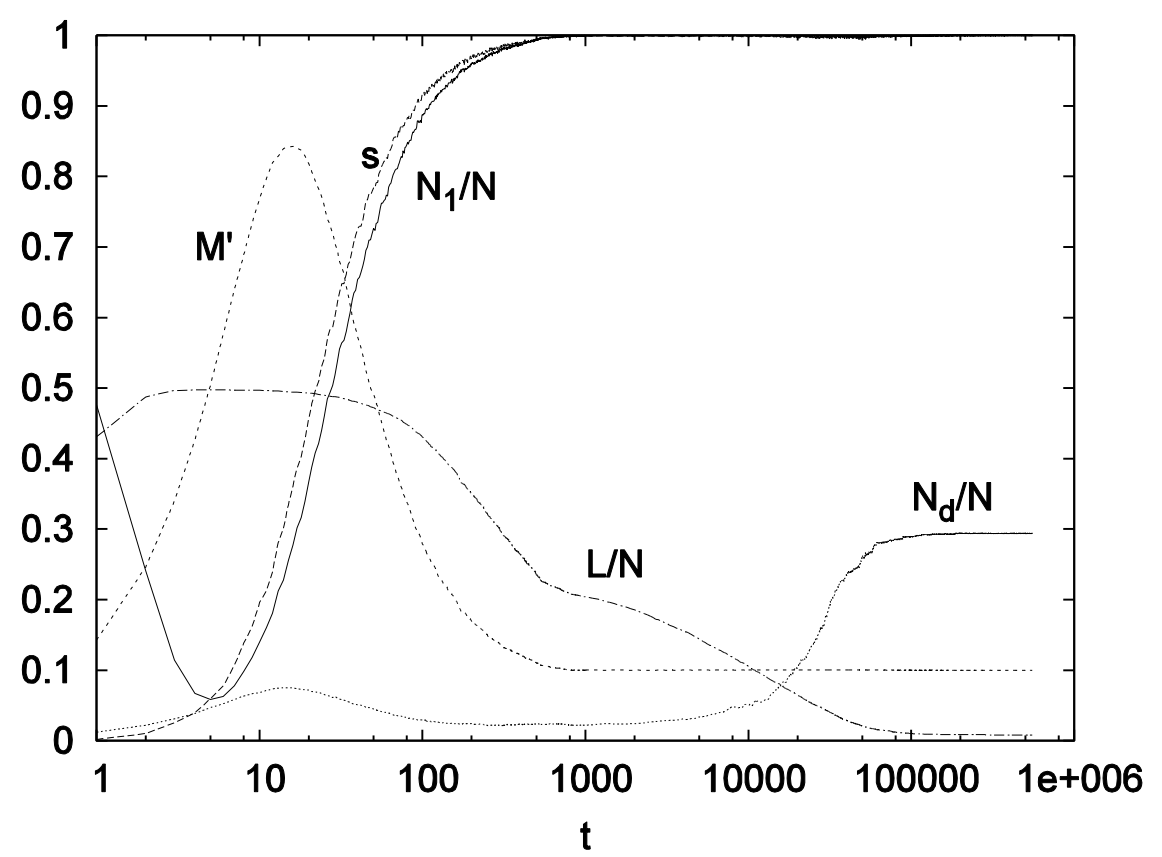

Ryc. 2 Zależność wartości pięciu parametrów modelu od czasu t (oś pozioma $w$ skali logarytmicznej) wyznaczona $w$ uktadzie o liczbie agentów $N=1000$ przy wartości parametru kontrolnego $N \varepsilon^{2}=10^{-9}$, czyli w reżimie wielojęzykowym. Te parametry to: (1) sukces komunikacyjny s, (2) stosunek liczby różnych słów do liczby agentów $\frac{L}{N}$, (3) odsetek agentów z jednym stowem $w$ stowniku $\frac{N_{1}}{N}$, (4) odsetek agentów używających dominującego języka $\frac{N_{d}}{N}$, (5) stosunek liczby $M$ wszystkich stów $w$ stownikach agentów do liczby agentów $N$

$$
\text { przeskalowany przez 1o, tzn. }{ }^{M^{\prime}}=\frac{M}{10^{4}} \text {. }
$$

Jak się więc okazuje, mamy tu do czynienia ze stabilnym stanem wielojęzykowym. W prowadzącym do niego rozwoju sytemu można wyróżnić trzy fazy. W pierwszej fazie $(t<1000)$ liczba różnych słów $\mathrm{w}$ słownikach agentów $L$ jest tak duża (początkowo nawet rzędu $\frac{N}{2}$ ), przy niewielkim zarazem średnim sukcesie komunikacyjnym ${ }^{s}$, że można ją chyba określić mianem prelingwistycznej. Stopniowo jednak liczba $L$ $N$

maleje (do około $\overline{5}$ ), zaś sukces rośnie. W fazie drugiej $(1000<t<30000$ ) prawie wszystkie agenty mają już tylko po jednym słowie w słowniku (jak widać na Ryc. 2, zarówno $N_{1}$ - liczba agentów z dokładnie jednym słowem w słowniku, jak i $M$ - liczba wszystkich słów w słownikach agentów są w zasadzie równe liczbie agentów ${ }^{N}$ ), zatem wszystkie agenty dysponują już 
określonym językiem. Tak więc wykształciła się pewna struktura klasterowa, nieco bardziej stabilna niż w fazie poprzedniej, gdyż jak widać, jednocześnie też zwalnia tempo spadku liczby języków $L$. Jak już wspomniano, mimo pełnego sukcesu komunikacyjnego utrzymuje się wciąż duża liczba języków i żaden z nich nie wyróżnia się jako dominujący.

Dopiero w fazie trzeciej $(t>30000$ ) wyłania się język dominujący: liczba jego użytkowników $N_{d}$ wzrasta do około $30 \%$ populacji (nie obejmuje więc całości, jak w reżimie jednojęzykowym). Jak pokazały dalsze symulacje układów o różnej wielkości, im większa jest liczba agentów ${ }^{N} \mathrm{w}$ systemie, tym szybciej i szerzej taki język rozprzestrzenia się $\mathrm{w}$ danym układzie (tzn. tym gwałtowniej zdobywa dominację i tym większą część populacji obejmuje). Niemniej nadal w użyciu pozostają też i inne języki, choć ich liczba spada ostatecznie do około dziesięciu.

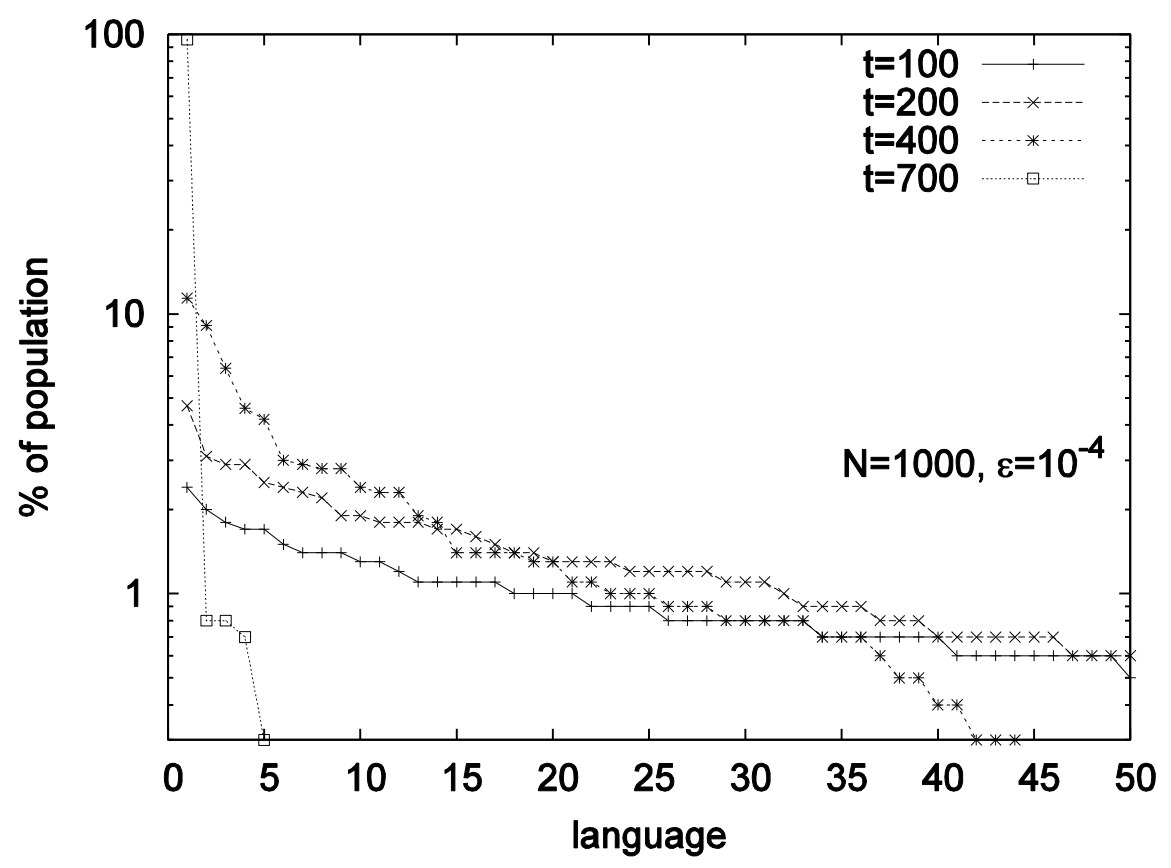

Ryc. 3 Procentowy rozkład liczebności (oś pionowa $w$ skali logarytmicznej) użytkowników 50 najpowszechniejszych języków wyznaczony $w$ uktadzie o liczbie agentów $N=1000$ oraz przy wartości parametru kontrolnego $N \varepsilon^{2}=10^{-5}$, tj. w reżimie jednojęzykowym, $w$ kilku wybranych momentach czasu

$$
t=100,200,400 \text { i } 700 \text {. }
$$


Dorota Lipowska: Gra w nazywanie z preferencyjnym wyborem partnerów

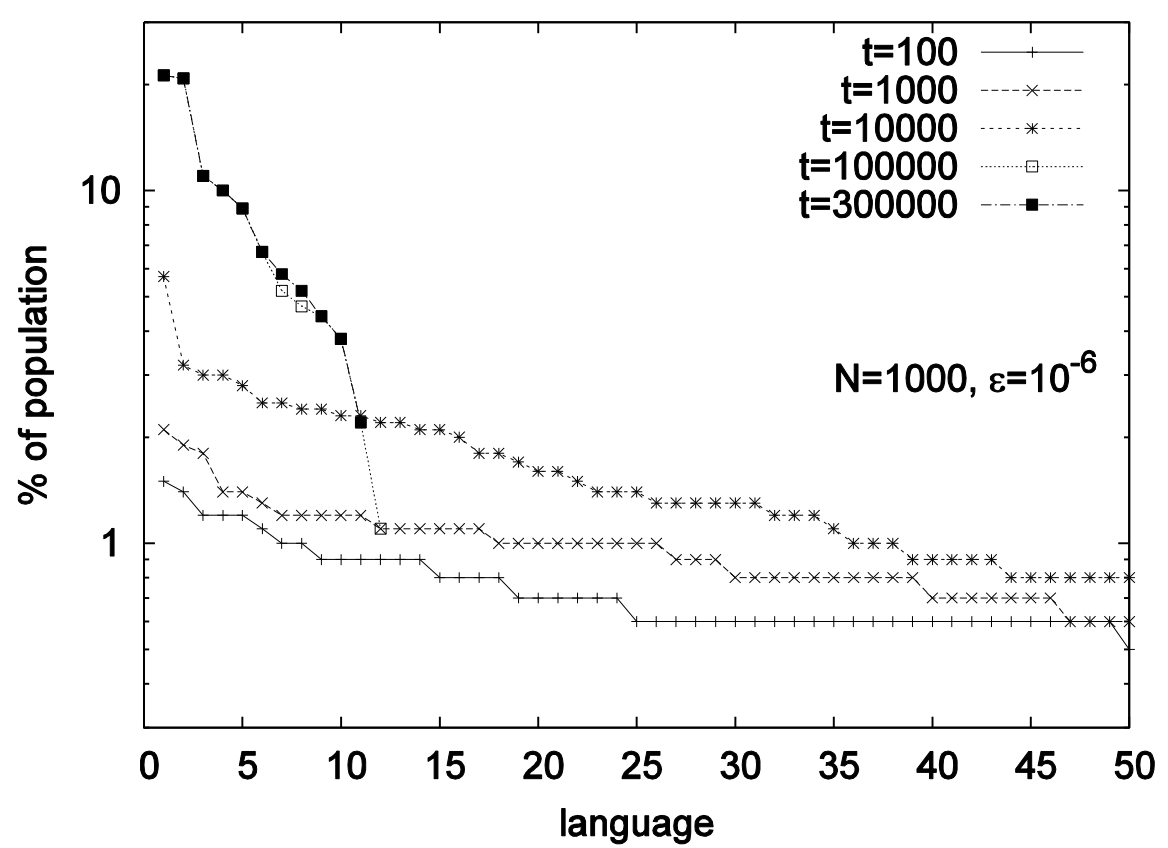

Ryc. 4 Procentowy rozkład liczebności (oś pionowa $w$ skali

logarytmicznej) użytkowników 5o najpowszechniejszych języków wyznaczony $w$ uktadzie o liczbie agentów $N=\mathbf{1 0 0 0}$ oraz przy wartości parametru kontrolnego $N \varepsilon^{2}=10^{-9}, t j$. w reżimie wielojęzykowym, $w$ kilku wybranych momentach czasu $t=100,1$ ooo, 10 ooo, 100 ooo i 300 ooo.

Dla badanego modelu zmierzone też zostały w obu reżimach (jednojęzykowym - Ryc. 3 oraz wielojęzykowym - Ryc. 4) liczebności użytkowników pięćdziesięciu najpowszechniejszych języków (przy stałej wielkości układu $N=1000$ ). Pierwsza rzucająca się w oczy różnica między obu reżimami to okres osiągania stanu stabilnego, który jest dużo dłuższy $\mathrm{w}$ reżimie wielojęzykowym $(t \approx 100000)$ niż $\quad \mathrm{w}$ jednojęzykowym $(t \approx 1000)$. W obu reżimach wobserwowanym czasie początkowo zwiększa się liczebność badanych języków kosztem innych (głównie tych jeszcze mniej rozpowszechnionych, tzn. spoza pierwszej pięćdziesiątki). Dopiero na końcowych etapach ewolucji systemu zanika także większość języków spośród owych 50: $\mathrm{w}$ reżimie jednojęzykowym w $t=700$ jest już zaledwie 5 języków, a w $t=1000$ - pozostaje praktycznie już tylko 1 język, natomiast $\mathrm{w}$ reżimie wielojęzykowym $\mathrm{w}^{t}=100000$ tych języków jest 12 (przy czym ich liczebności pozostają właściwie bez większych zmian aż do $t=300000$, kiedy to zanika jeszcze jeden język o najmniejszej liczbie użytkowników). Kolejna wyraźna różnica między reżimami, to skala dominacji najpowszechniejszego języka. W przypadku jednojęzykowym języka dominującego (pierwszego na liście 50 badanych języków) $\mathrm{w}$ momencie $t=100$ używa około $2,5 \%$ populacji, w $t=700$ - już $96 \%$, 
$\mathrm{a} \mathrm{w}^{t=1000}-$ jest to ponad 99\%. Natomiast w przypadku wielojęzykowym odsetki te wynoszą odpowiednio $1,5 \%$ dla $t=700$ i $2 \%$ dla $t=1000$, także później bardzo powoli rosną, np. do zaledwie $6 \%$ dla $t=10000$, zaś po bardzo długim czasie $t=100000$ jest to wciąż tylko $21 \%$ - i na tym poziomie sytuacja wreszcie się stabilizuje. Ponadto wszystkie pozostałe wówczas języki mają zbliżoną liczebność (od $2 \%$ do 21\% populacji). Tak więc ewolucja modelu istotnie przebiega różnie $\mathrm{w}$ dwóch zaobserwowanych reżimach, przy czy można zauważyć, że o przeżyciu języka nie decyduje sama tylko liczba jego użytkowników, ale także wartość parametru kontrolnego $N \varepsilon^{2}$ (w początkowych stadiach rozwoju stanu jednojęzykowego także istnieją różne języki o dużych liczebnościach, podobnie jak w reżimie wielojęzykowym, a jednak wszystkie one zostają szybko wyeliminowane przez jeden jedyny język, obejmujący w końcu całą populację).

Oczywiście nasuwa się pytanie, czy zachowanie omawianego modelu można porównywać z ewolucją języka naturalnego. Aktualnie wciąż jeszcze istnieje kilka tysięcy języków etnicznych, jednak liczba ich wciąż się zmniejsza, nie jest to więc nadal stan stabilny. Trudno oczywiście przewidzieć, czy dalsza ewolucja doprowadzi nas do stanu jedno- czy wielojęzykowego. Porównując np. dane statystyczne dotyczące liczby użytkowników poszczególnych języków (Weber, 1997) z analogicznymi danymi uzyskanymi w modelu (Ryc. 5), widzimy dość dobrą ich zgodność, zwłaszcza dla reżimu wielojęzykowego. Symulacje komputerowe w tym reżimie prowadzone były aż do osiągnięcia przez liczbę użytkowników języka dominującego w modelu 20,7\% populacji (co odpowiada liczbie użytkowników języka chińskiego, dominującego według danych Webera). Jak widać, także mniej liczebne języki wykazują dość dobrą zgodność z danymi statystycznymi Webera (a prawdopodobnie można by ją jeszcze poprawić modyfikując wartość parametru kontrolnego modelu $N \varepsilon^{\mathbf{2}}$ ). Oczywiście taka zbieżność może być jednak przypadkowa i nie musi wynikać z analogicznego przebiegu ewolucji języka naturalnego i języka agentów. Mechanizmy leżące u podstaw ewolucji języka człowieka są tak niezwykle złożone, że na pewno nie da się ich opisać przez tak prosty model. Niemniej można żywić nadzieję, że model prezentowany tutaj poprawnie opisuje choćby pewien aspekt tego skomplikowanego procesu. 
Dorota Lipowska: Gra w nazywanie z preferencyjnym wyborem
partnerów

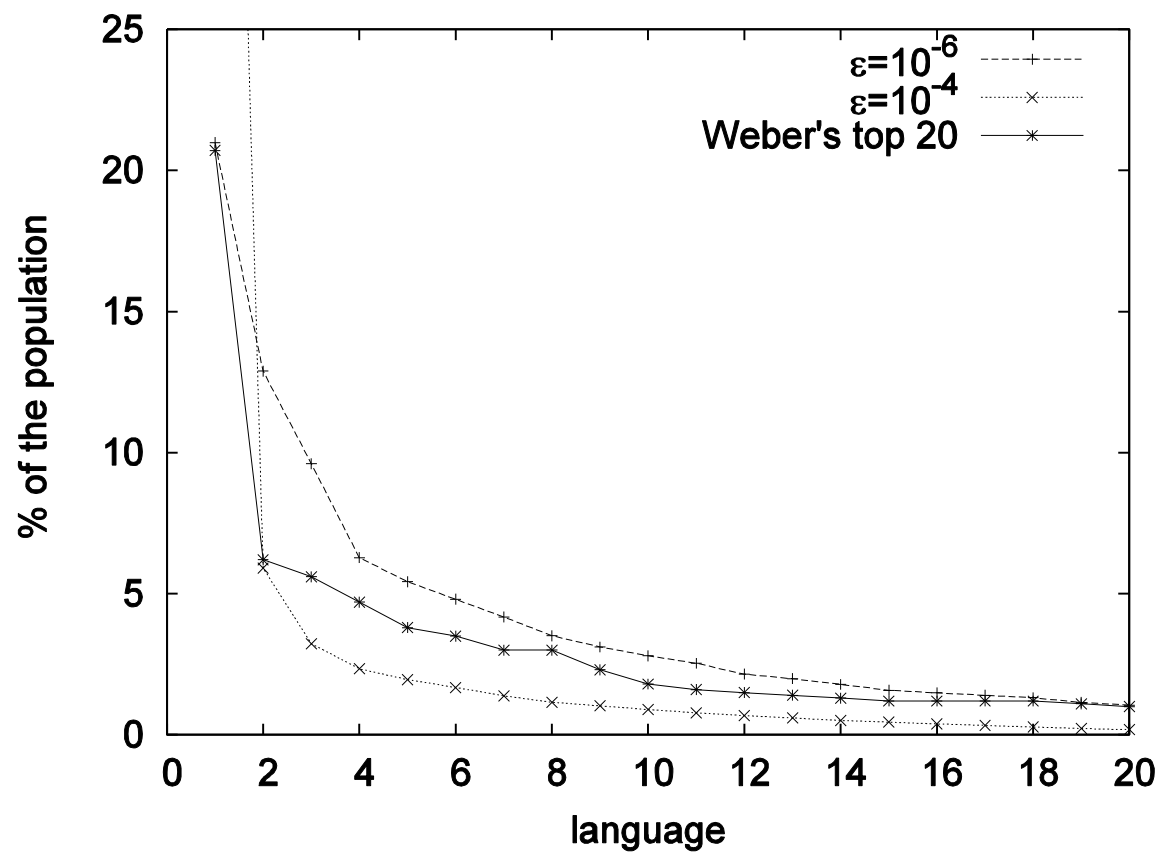

Ryc. 5 Procentowy rozkład liczebności użytkowników 20 najpowszechniejszych języków wyznaczony $w$ układzie o liczbie agentów $N=1000$ oraz dla dwóch wartości parametru $\varepsilon \quad\left(\varepsilon=10^{-4}\right.$, tj. w reżimie jednojęzykowym, oraz $\varepsilon=10^{-6}$, tj. $w$ reżimie wielojęzykowym) $w$ porównaniu z danymi statystycznymi Webera (Weber, 1997), wedhug których np. 3 pierwsze języki to: chiński (20,7\% populacji, tj. 1,1 $\cdot 10^{9}$ użytkowników), angielski $\left(6,2 \%-3,2 \cdot \mathbf{1 0}^{8}\right)$ i hiszpański $(5,6 \%-3,0$ $\left.\cdot 10^{8}\right)$.

\section{Podsumowanie}

W niniejszej pracy przedstawiony został model gry $\mathrm{w}$ nazywanie na adaptatywnej sieci ważonej, w którym intensywność kontaktów między agentami wyznaczona jest przez preferowanie partnerów z wyższym poziomem sukcesu odniesionego w dotychczasowej komunikacji. Gdy ta preferencja nie jest zbyt silna, model zachowuje się podobnie jak model gry w nazywanie na grafie pełnym, tzn. bardzo szybko osiąga stan pełnej lingwistycznej synchronizacji, w którym wszystkie agenty używają tego samego języka. Inaczej jednak niż dla grafu pełnego, w którym czas osiągnięcia takiego stanu rozbiega się jak $N^{1.5}$ wraz z liczbą agentów $N$, w omawianym modelu czas ten jest zbieżny do pewnej stałej wartości. Ponadto nieco niższe od oczekiwanego dla grafu pełnego jest też tempo wzrostu średniej maksymalnej liczby słów w słownikach agentów (unormowanej przez liczbę agentów) ze wzrostem liczby agentów ( $N^{0.45}$ wobec spodziewanego $N^{0.5}$ ).

Natomiast zupełnie inne i dużo bardziej interesujące zachowanie modelu można zaobserwować w przypadku, gdy preferencje wyboru partnerów interakcji są silniejsze. Wówczas stan pełnej lingwistycznej 
synchronizacji nie jest osiągany i układ stabilizuje się w stanie wielojęzykowym, choć o stosunkowo niewielkiej liczbie języków i z jednym językiem dominującym. Spekulując na temat przebiegu ewolucji języka naturalnego w sposób analogiczny do przedstawionego modelu, należałoby chyba optować za scenariuszem wielojęzykowym, nie tylko zresztą ze względu na lepszą zgodność danych demolingwistycznych Webera $\mathrm{z}$ odpowiednimi wynikami modelu działającego w tym reżimie. Aktualnie ciągle jeszcze liczymy języki etniczne w tysiącach i mimo szyblkiego tempa wymierania tych najrzadszych oraz mimo postępującego procesu globalizacji i homogenizacji populacji ludzi, nie widać na razie takich mechanizmów, które by spowodować miały zniknięcie wszystkich języków oprócz tylko jednego. Bardziej prawdopodobna wydaje się chyba sytuacja - w bardzo odległej jeszcze przyszłości - w której pozostanie jednak pewna większa liczba języków (kilka? kilkaset?). Czy wyginięcie tych najmniej rozpowszechnionych języków doprowadzi do wyłonienia się języka dominującego, tak jak dzieje się to $\mathrm{w}$ ostatniej fazie reżimu wielojęzykowego modelu - a jeśli tak, to kiedy by to mogło nastąpić? Dokładnej odpowiedzi nie da się oczywiście uzyskać na podstawie modelu, ale można np. z danych dotyczących zmienności w czasie liczebności języka dominującego zauważyć, że jego rola zaczyna się wyraźniej zaznaczać, a tempo jego wzrostu nabiera gwałtownego przyspieszenia wówczas, gdy obejmuje on około $20 \%$ populacji agentów. Tak więc $\mathrm{z}$ faktu, że użytkownicy języka chińskiego stanowią taki właśnie odsetek populacji ludzi można by wnioskować, że zbliżamy się do takiego właśnie momentu. Oczywiście do tego rodzaju spekulacji trzeba podchodzić z dużą dozą ostrożności i sceptycyzmu, pamiętając o niezwykle skomplikowanej naturze języka i jego niebywale złożonej ewolucji wyznaczonej przez wiele różnorodnych procesów.

\section{Podziękowania}

Praca finansowana z grantu NCN 2011/01/B/HS2/O1293. 


\section{Dorota Lipowska: Gra w nazywanie z preferencyjnym wyborem partnerów}

\section{Bibliografia}

Albert, R. i Barabási, A. (2002). Statistical mechanics of complex networks. Reviews of Modern Physics, 74, strony 47-97.

Baronchelli, A., Dall'Asta, L., Barrat, A. i Loreto, V. (2007). Nonequilibrium phase transition in negotiation dynamics. Physical Review E, 76, str. 051102.

Baronchelli, A., Dall'Asta, L., Barrat, A. i Loreto, V. (2005). Topology Induced Coarsening in Language Games. Physical Review E, 73, str. 015102.

Baronchelli, A., Felici, M., Loreto, V., Caglioti, E. i Steels, L. (2006). Sharp transition towards shared vocabularies in multi-agent systems. Journal of Statistical Mechanics, 6, str. P06014.

Baronchelli, A., Loreto, V. i Steels, L. (2008). In-depth analysis of the naming game dynamics: The homogeneous mixing case. International Journal of Modern Physics C, 19(5), strony 785--812.

Baronchelli, A., Loreto, V., Dall'Asta, L. i Barrat, A. (2006). Bootstrapping communication in language games: strategy, topology and all that. W A. Cangelosi, A. Smith i K. Smith (Redaktorzy), The Evolution of Language: Proceedings of the 6th International Conference on the Evolution of Language (strony 11-18). Singapore: World Scientific.

Brighton, H., Kirby, S. i Smith, K. (2003). Situated cognition and the role of multi-agent models in explaining language structure. W E. Alonso, D. Kudenko i D. Kazakov (Redaktorzy), Adaptive Agents and Multi-Agent Systems: Adaptation and Multi-Agent Learning (strony 88-109). Springer-Verlag.

Brighton, H., Smith, K. i Kirby, S. (2005). Language as an evolutionary system. Physics of Life Reviews, 2(3), strony 177-226.

Briscoe, E. (Red.). (2002). Linguistic Evolution through Language Acquisition: Formal and Computational Models. Cambridge: Cambridge University Press.

Cangelosi, A. i Parisi, D. (Redaktorzy). (2002). Simulating the Evolution of Language. London: Springer-Verlag.

Christiansen, M. i Kirby, S. (Redaktorzy). (2003a). Language Evolution. New York: Oxford University Press.

Christiansen, M. i Kirby, S. (2003b). Language Evolution: Consensus and Controversies. Trends in Cognitive Sciences, 7(7), strony 300-307.

da Silva Filho, R., Brust, M. i Ribeiro, C. (2009). Consensus Dynamics in a nondeterministic Naming Game with Shared Memory. CoRR, abs/0912.4553. Pobrano z lokalizacji http://arxiv.org/abs/0912.4553

Dall'Asta, L., Baronchelli, A., Barrat, A. i Loreto, V. (2006a). Agreement dynamics on small-world networks. Europhysics Letters, 73(6), strony 969-975.

Dall'Asta, L., Baronchelli, A., Barrat, A. i Loreto, V. (2006b). Nonequilibrium dynamics of language games on complex networks. Physical Review E, 74, str. 036105.

De Beule, J. (2011). A Chemical Model of the Naming Game. W G. Kampis, I. Karsai i E. Szathmáry (Redaktorzy), Advances in Artificial Life (ECAL09) (strony 466-473). Springer.

de Boer, B. (2006). Computer modelling as a tool for understanding language evolution. W N. Gontier, J. van Bendegem i D. Aerts (Redaktorzy), Evolutionary Epistemology, Language and Culture - A non-adaptationist, systems theoretical approach (strony 381-406). Dordrecht: Springer.

de Oliveira, P., Stauffer, D., Wichmann, S. i de Oliveira, S. (2008). A computer simulation of language families. Journal of Linguistics, 44, strony 659-675. 


\section{Investigationes Linguisticae, vol. $X X V$}

de Vylder, B. i Tuyls, K. (2006). How to reach linguistic consensus: A proof of convergence for the naming game. Journal of Theoretical Biology, 242(4), strony 818831.

Gontier, N., van Bendegem, J. i Aerts, D. (Redaktorzy). (2006). Evolutionary Epistemology, Language and Culture - A non-adaptationist, systems theoretical approach. Dordrecht: Springer.

Hurford, J., Studdert-Kennedy, M. i Knight, C. (Redaktorzy). (1998). Approaches to the Evolution of Language. Cambridge: Cambridge University Press.

Kirby, S. (2002). Natural Language from Artificial Life. Artificial Life, 8(2), strony 185215.

Kirby, S. (2007). The evolution of language. W R. Dunbar i L. Barrett (Redaktorzy), Oxford Handbook of Evolutionary Psychology (strony 669-681). Oxford : Oxford University Press.

Kirby, S. i Christiansen, M. (2003). From language learning to language evolution. W M. Christiansen i S. Kirby (Redaktorzy), Language Evolution (strony 272-294). Oxford University Press.

Kirby, S. i Hurford, J. (2002). The emergence of linguistic structure: An overview of the iterated learning model. W A. Cangelosi i D. Parisi (Redaktorzy), Simulating the Evolution of Language (strony 121-148). London: Springer Verlag.

Knight, C., Studdert-Kennedy, M. i Hurford, J. (Redaktorzy). (2000). The Evolutionary Emergence of Language. Cambridge: Cambridge University Press.

Laks, B. (Red.). (2008). Origin and Evolution of Languages: Approaches, Models, Paradigms. London: Equinox Publishing.

Lenaerts, T., Jansen, B., Tuyls, K. i de Vylder, B. (2005). The evolutionary language game: An orthogonal approach. Journal of Theoretical Biology, 235(4), strony 566582.

Lin, B., Ren, J., Yang, H. i Wang, B. (2006). Naming game on small-world networks: the role of clustering structure. Pobrano z lokalizacji arXiv:physics/0607001

Lipowska, D. (2011a). Naming game on adaptive weighted networks. (wysłano do druku). Pobrano z lokalizacji arXiv:1107.3263

Lipowska, D. (2011b). Naming game and computational modelling of language evolution. Computational Methods in Science and Technology, 17(1), str. (in print).

Lipowski, A. i Lipowska, D. (2008). Bio-linguistic transition and the Baldwin effect in the evolutionary naming game model. International Journal of Modern Physics C, 19, strony 399-407.

Lipowski, A. i Lipowska, D. (2009). Language structure in the n-object naming game. Physical Review E, 80, str. 056107.

Liu, R.-R., Jia, C.-X., Yang, H.-X. i Wang, B.-H. (2009). Naming game on small-world networks with geographical effects. Physica A: Statistical Mechanics and its Applications, 388(17), strony 3615-3620.

Loreto, V., Baronchelli, A., Mukherjee, A., Puglisi, A. i Tria, F. (2011). Statistical physics of language dynamics. Journal of Statistical Mechanics, 4, str. P04006.

Lu, Q., Korniss, G. i Szymanski, B. (2009). The Naming Game in Social Networks: Community Formation and Consensus Engineering. Journal of Economic Interaction and Coordination, 4, str. 221.

Lu, Q., Korniss, G. i Szymanski, B. K. (2006). Naming Games in Spatially-Embedded Random Networks. W Proc. AAAI Fall Symposium Series, Interaction and Emergent Phenomena in Societies of Agents (strony 148-155). Menlo Park, CA: AAAI Press. 


\section{Dorota Lipowska: Gra w nazywanie z preferencyjnym wyborem partnerów}

Lu, Q., Korniss, G. i Szymanski, B. K. (2008). Naming games in two-dimensional and small-world-connected random geometric networks. Physical Review E, 77(1), str. 016111.

Nolfi, S. i Mirolli, M. (Redaktorzy). (2010). Evolution of Communication and Language in Embodied Agents. Berlin, Heidelberg: Springer-Verlag.

Nowak, M. i Komarova, N. (2001). Towards an evolutionary theory of language. Trends in Cognitive Sciences, 5, strony 288-295.

Nowak, M. i Krakauer, D. (1999). The evolution of language. Proceedings of the National Academy of Sciences, 96(14), strony 8028-8033.

Pinker, S. i Bloom, P. (1990). Natural language and natural selection. Behavioral and Brain Sciences, 13, strony 707-784.

Schulze, C., Stauffer, D. i Wichmann, S. (2008). Birth, survival and death of languages by Monte Carlo simulation. Communications in Computational Physics, 3, strony 271294.

Scott-Phillips, T. i Kirby, S. (2010). Language evolution in the laboratory. Trends in Cognitive Sciences, 14(9), strony 411-417.

Smith, K., Kirby, S. i Brighton, H. (2003). Iterated Learning: a framework for the emergence of language. Artificial Life, 9(4), strony 371-386.

Steels, L. (1995). A self-organizing spatial vocabulary. Artificial Life, 2(3), strony 319332.

Steels, L. (1996). Self-organizing vocabularies. W C. Langton i K. Shimohara (Redaktorzy), Artificial Life V (strony 179-184). MIT Press.

Steels, L. (1997). The Synthetic Modeling of Language Origins. Evolution of Communication Journal, 1(1), strony 1-34.

Steels, L. (2000). Language as a Complex Adaptive System. W M. Schoenauer (Red.), Proceedings of PPSN VI (Lecture Notes in Computer Science). Berlin: SpringerVerlag.

Steels, L. (2002). Iterated Learning versus Language Games. Two models for cultural language evolution. W C. Hemelrijk i E. Bonabeau (Redaktorzy), Proceedings of the International Workshop of Self-Organization and Evolution of Social Behaviour. Zurich: University of Zurich.

Steels, L. (2004). Social and cultural learning in the evolution of human communication. W D. Kimbrough Oller i U. Griebel (Redaktorzy), Evolution of communication systems : A comparative approach (strony 69-90). Cambridge, MA: The MIT Press.

Steels, L. (2005). The emergence and evolution of linguistic structure: from lexical to grammatical communication systems. Connection Science, 17(3-4), strony 213-230.

Steels, L. i McIntyre, A. (1999). Spatially Distributed Naming Games. Advances in Complex Systems, 1(4), strony 301-323.

Wasserman, S. i Faust, K. (1994). Social network analysis: methods and applications. Cambridge: Cambridge University Press.

Weber, G. (1997). Top Languages: The World's 10 Most Influential Languages. Language Today, 2. Pobrano z lokalizacji http://www.andaman.org/BOOK/reprints/ weber/Weber-TopTen.htm

White, H., Boorman, S. i Breiger, R. (1976). Social structure from multiple networks: I. Block-models of roles and positions. American Journal of Sociology, 81, strony 730780 . 